IP Periodica Polytechnica Civil Engineering

61(1), pp. 146-153, 2017

DOI: 10.3311/PPci.9501

Creative Commons Attribution (i)

RESEARCH ARTICLE

\section{Comparison of Different Standards Based on Computing the Probability of Failure of Flood Protection Dikes}

\author{
István Kádár ${ }^{*}$, László Nagy ${ }^{1}$
}

Received 18-05-2016; accepted 14-06-2016

\begin{abstract}
Flood damage poses a major threat to many countries across Europe. One of the most disadvantageous communities is Hungary, especially in view of the fact that $23 \%$ of the total area is situated on floodplain. 97\% of this region is protected by flood control dikes and the remaining 3\% is generally low-value zone. Through the decades different design methods referring to flood protection dikes have been recommended with newer and newer safety factors. In a few areas of geotechnical engineering - with the presence of Eurocode 7 - the reliability based design came to the front. The performance of a certain embankment cannot be compared by considering only the safety factors of the different theories but based on computing the probability of failure values it becomes possible. The article aims to show a method of how to define the input parameters and calculate the probability of failure of a flood protection dike. Hence the reliability of different standards can be compared.
\end{abstract}

\section{Keywords}

geotechnics, probability of failure, flood protection dike, Monte Carlo simulation, factor of safety

\section{Introduction, problem statement}

Flooding is a recurrent issue in Hungary. Therefore the examination of the stability of flood protection dikes has given many research projects to professionals [1]. There are two options to predict the probability of failure of a dike. The first one is to observe and evaluate historical data statistically and based on experience trying to forecast the expected failure mode. This method can be applied for phenomena which we cannot handle by calculations (e.g. piping). However there are failure mechanisms which can be avoided by careful planning and calculations. In the first part of the article Hungarian and international data are collected together referring to various failure mechanisms of dams and dikes while the second part is focused on slope stability. By this failure mode the probability of failure can be calculated.

The observations, field experience, scientific results and the demand on regulation lead to creating standards. The Hungarian national standards were in force until the introduction of Eurocode standards. In 2010 Eurocode 7 changed the national standard (MSZ series) in geotechnics. With the presence of Eurocode 7 Standard the reliability-based design appeared in which it is essential that we know the physical parameters of the soils as accurately and safely as possible [2]. Simple reliability analyses require little effort beyond that involved in conventional geotechnical analyses [3, 4]. The comparison of the two standards cannot be made based on only the prescribed factor of safety as the national standard uses mean values while Eurocode uses characteristic values as input parameters for calculation. The determination of the characteristic values is detailed below and an example is also described. Based on this the level of safety of different standards is comparable.

\section{Failure mechanisms of dams and dikes based on statistics}

Many researchers have made data acquisition of failure mechanisms of dams and dikes. In 1953 Middlebrooks [5] collected a set about North American dike failures and his work was followed by many others. Nowadays large data sets are available not only listed by countries but detailing 
in international bulletins (e.g. ICOLD - International Comission on Large Dams and USCOLD - United States Society on Dams) [6-9]. Evaluating historical data can help in estimation of probability of failure but the following issues can occur by the use of it:

- time-related and spatial variability of the events;

- the statistical data may not refer to the same events,

- often difficult the define tendency in data.

Table 1 shows the failure mechanisms of large dams based on the collection of Gruner [10], Middlebrooks [5], Takase [11] and Babb\&Mermel [12]. The data of the different authors are in accordance. It can be stated that $23-38 \%$ of the total failures are in connection with overtopping while failures due to seepage have the highest rate with $30-44 \%$. The percentage of slope slides and other failures are lower compared to the rate of the above-mentioned mechanisms.

Table 1 Distribution of failure mechanisms of large dams

\begin{tabular}{lllll}
\hline Failure mechanism & Overtopping & $\begin{array}{l}\text { Piping / } \\
\text { seepage }\end{array}$ & $\begin{array}{l}\text { Slope } \\
\text { slides }\end{array}$ & Other \\
\hline Gruner (1967) & 23 & 40 & 2 & 35 \\
Middlebrooks (1953) & 30 & 38 & 15 & 17 \\
Takase (1967) & 28 & 44 & 10 & 18 \\
USCOLD (1973) & 38 & 44 & 9 & 9 \\
Babb\&Mermel (1968) & 36 & 30 & 15 & 19 \\
\hline
\end{tabular}

Similar statistics have not been available for flood dikes and other types of dams/dikes for a long time. However many dike failures occurred due to flooding e.g.:

- in 1953 more than 400 dike failures happened in the Netherlands,

- in 1993103 dike breaches occurred on Mississippi river,

- in 1997140 dike failures were registered by flood in California.

By comparing the characteristics of the dams which have experienced failures and accidents to undamaged dams, it is possible to assess the relative influence of particular factors on the likelihood of piping and slope instability [13].

In Table 2 the distribution of failure mechanisms of flood dikes, canal dikes, sea dikes and large dams are collected and summarized.

The collected cases refer to damage or an irreversible failure as marked in the second row of the table. Table 2 includes data for large dams, flood dikes, canal dikes and sea dikes. More authors confuse failure mechanisms with the reasons of failure. Construction fault, ice drift, earthquake etc. are not failure mechanisms but reasons. The harmonisation of the categories would make the comparison easier.

Comments in connections with Table 2:

- the data set according to Krol [14] consists of Polish events which are damages (not failures) and the mechanisms are mixed up with reasons;
- Sametz collected 115 Austrian failures [15] referring to dams, flood dikes and canal dikes;

- the Japanese literature according to Fukunari divided the failures into 4 groups [16]. The events are from 1947 to 1969 and the total number is 283 . With 231 failures overtopping has the highest rate. Piping, hydraulic failure and internal erosion are lumped together;

- Baars summarized 1735 failure events in his work [17] from 1134 to 2003 time interval. All events' failure mechanisms are known and none of them was a construction fault;

- based on Table 2 it can be concluded that overtopping has the highest rate (32-67\%) among the different failure mechanisms;

$24-60 \%$ of the total failures are in connection with geotechnical design, such as seepage, subsoil failure due to not sufficient bearing capacity, erosion.

Table 2 Failure mechanisms and damages of large dams/flood dikes/canal dikes/sea dikes

\begin{tabular}{|c|c|c|c|c|c|c|}
\hline author/research & Sametz & Krol & Fukunari & ICOLD & ICOLD & Baars \\
\hline damage/failure & $\mathrm{f}$ & $\mathrm{d}$ & $\mathrm{f}$ & $\mathrm{f}$ & $\mathrm{d}$ & $\mathrm{f}$ \\
\hline year of publication & 1981 & 1983 & 2008 & 1984 & 1974 & 2009 \\
\hline $\begin{array}{l}\text { large dam-flood dike- } \\
\text { canal dike-sea dike }\end{array}$ & $1 / \mathrm{f} / \mathrm{c}$ & $\mathrm{f}$ & $\mathrm{f}$ & 1 & 1 & $f / s$ \\
\hline unit & pc. & $\%$ & pc. & $\%$ & $\%$ & $\%$ \\
\hline overtopping & 43 & 32 & 231 & & & 67 \\
\hline breach & 12 & & & & & \\
\hline
\end{tabular}

seepage in
embankment

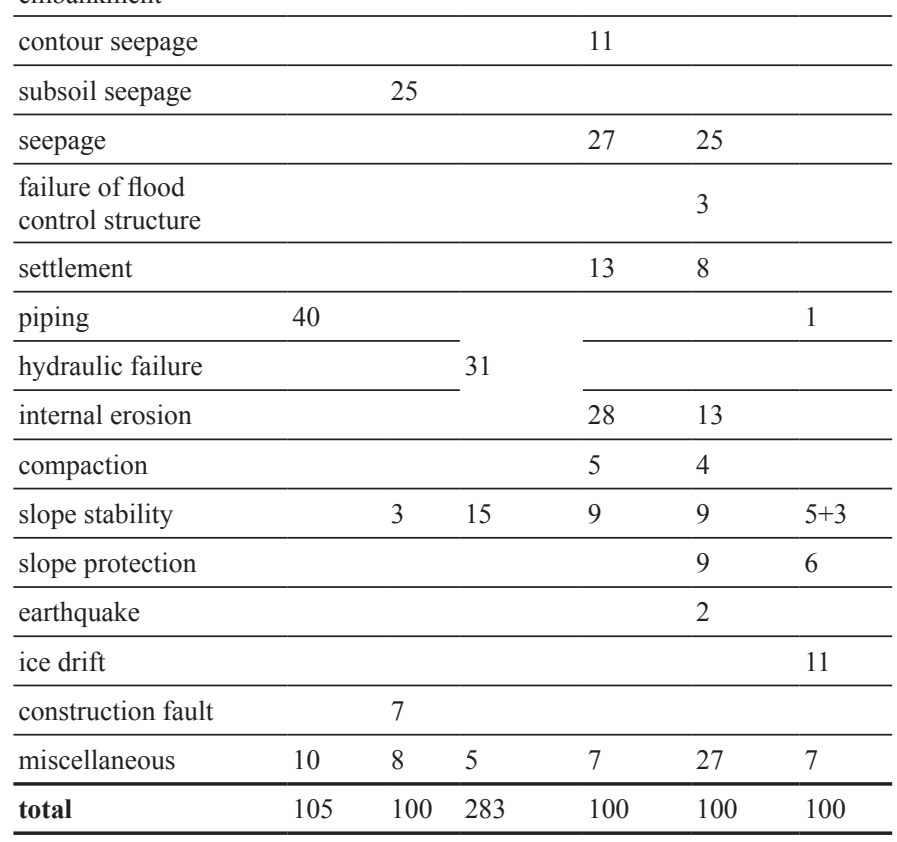

A statistical evaluation of dike failures during the severe flood at the Elbe and Mulde river in Saxony (Germany) in 2002 has been studied by Horlacher [18]. 38 breaches at homogeneous dikes have been observed and analyzed with respect to a governing failure mechanism. Figure 1 shows the dike 
breaches at homogeneous dike stretches during the flood 2002 in Saxony with respect to major failure modes. Overflow can be identified as the governing failure mechanism, slope instability and uplift/piping show a similar frequency of occurrence. [19]

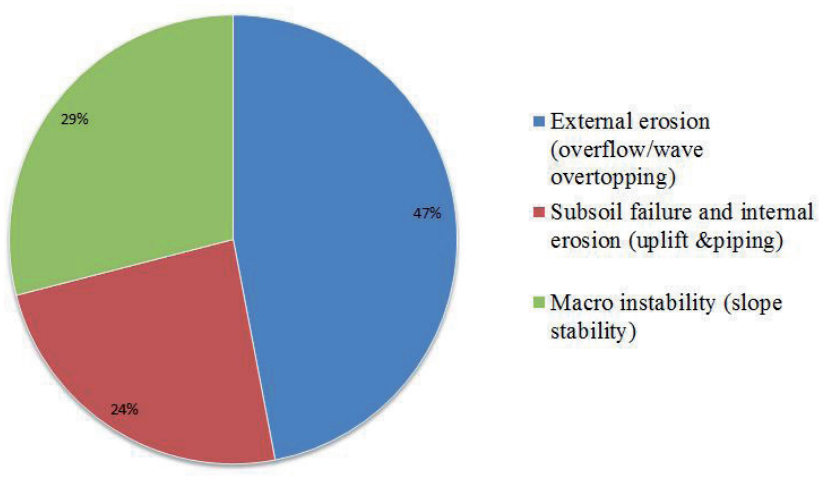

Fig. 1 Frequency of dike breaches at homogeneous dike stretches during the flood 2002 in Saxony

Table 3 describes the rate of different failure modes registered in the Carpathian Basin between 1564 and 2010. The data refers to more than 1200 failures [20].

Table 3 Failure mechanisms registered in the Carpathian Basin between 1564 and 2010

\begin{tabular}{ll}
\hline Failure mechanism & Rate $(\%)$ \\
\hline Overtopping & 77.5 \\
Vandalism & 5.5 \\
Deterioration & 4.8 \\
Subsoil failure & 4.3 \\
Wave erosion & 2.4 \\
Failure of flood control structure & 2.6 \\
Miscellaneous & 2.9 \\
\hline
\end{tabular}

Fig. 1 shows the failures in the Carpathian Basin as a pie chart.

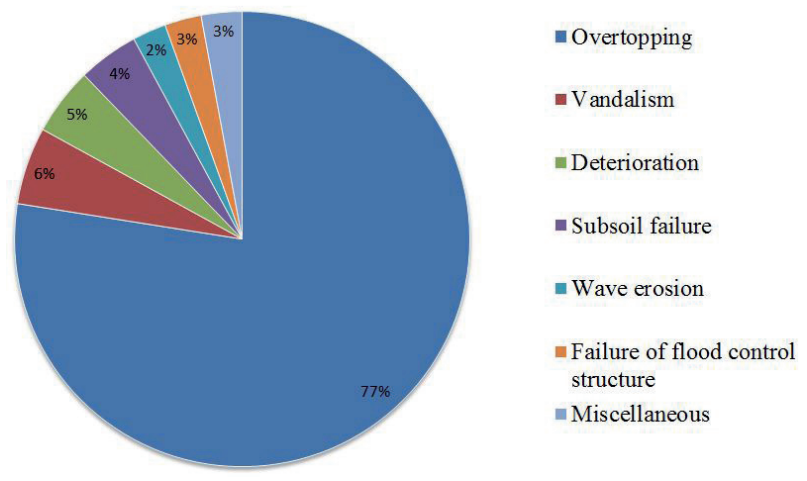

Fig. 2 Failure mechanisms in the Carpathian Basin between 1564 and 2010

Overtopping occurs when the prediction of the water stage or flood discharge is false or low return period is taken into account. Dealing with this problem is more a hydrological issue than geotechnical. In the followings the article is focused on slope stability as a failure mode of flood dikes.

\section{Probability of failure and related terminology 3.1 Probability of failure and reliability index}

The "probability of failure" $\left(P_{f}\right)$ is the probability that failure will occur. In terms of factor of safety $(F S)$, the probability of failure is defined as the probability that the factor of safety could be less than 1.0 given adverse values of the variables involved in the calculation. Estimating the probability of failure is a major motive for applying probability theory in geotechnical engineering.

Reliability is the complement of the probability of failure. For example, if there is a $0.5 \%$ probability that the factor of safety against slope instability may be less than 1.0 , the probability of failure is $0.5 \%$ and the reliability is $99.5 \%$.

The reliability index $(\beta)$ is the number of standard deviations between the most likely value of factor of safety and factor of safety $=1.0$. The reliability index is uniquely related to probability of failure, as shown in Table 4 . The values of $\mathrm{P}_{\mathrm{f}}$ apply to both normally distributed and lognormally distributed factors of safety.

Table 4 Relationship between reliability index and probability of failure

\begin{tabular}{ll}
\hline Reliability index $(\beta)$ & Probability of failure $\left(\mathrm{P}_{\mathrm{f}}\right)$ \\
\hline 0.50 & $31 \%$ \\
1.00 & $16 \%$ \\
1.50 & $6.7 \%$ \\
2.00 & $2.3 \%$ \\
2.50 & $0.62 \%$ \\
3.00 & $0.13 \%$ \\
4.00 & $0.003 \%$ \\
5.00 & $0.00003 \%$ \\
\hline
\end{tabular}

Because $\beta$ is uniquely related to the probability of failure, the value of $\beta$ has sometimes been used in lieu of the probability of failure as a measure of safety. However, in order to evaluate $\beta$, the distribution of the factor of safety must be assumed. Therefore, whether the value of $\beta$ or the value of $\mathrm{P}_{\mathrm{f}}$ is used as the safety criterion, it is necessary to assume a distribution for factor of safety [21].

According to the probabilistic approach, the resistance of a structure, the stresses and other effects are stochastic variables. If the distributions of the stochastic variables are known, subtracting the side of effect from the side of resistance leads to getting the resulting function, which shows us the value of probability of failure at the intersection point of the function and the ordinate axis. As expected the probability of failure can be determined with the aid of probability density functions too, as shown in Figure 1. 


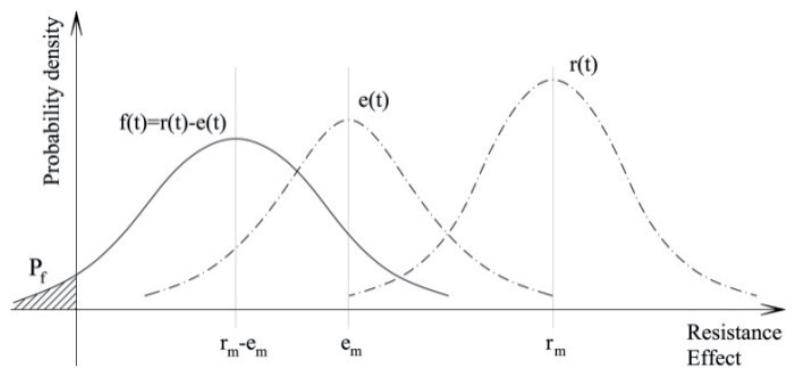

Fig. 3 Probability density functions and interpretation of probablity of failure

Equation (1) contains the connection between probability distribution functions and probability of failure, Eq. (2) introduces how to calculate probability of failure with probability density functions. The letter $f$ represents the performance function, $r$ is the function related to the resistances and $e$ is to the effects:

$$
\begin{gathered}
F(t)=R(t)-E(t) ; F(0)=P_{f} \\
f(t)=r(t)-e(t) ; \int_{-\infty}^{0} f(t) d t=P_{f}
\end{gathered}
$$

When using probabilistic methods the structure only meets the requirements about the probability of failure if it is not higher than the optimum of probability of failure, which belongs to the undesired conditions, which can be determined from cost optimizations $[22,23]$. The mathematical formula is shown in Eq. (3).

$$
\operatorname{Pr} o b\left\{[R(t)-E(t)]=\Delta_{R E}(t)<0\right\} \leq P_{f, o p t}
$$

\subsection{Normal distribution}

Normal distribution is commonly used for statistical analysis in geotechnical engineering. The distributions of many random variables conform to this distribution. It is generally used for probabilistic studies in geotechnical engineering unless there are good reasons for selecting a different distribution. Typically, variables which arise as a sum of a number of random effects, none of which dominate the total, are normally distributed.

Having estimated the mean $(\mu)$ and standard deviation $(\sigma)$, the probability density function for a normal distribution is defined by Eq. (4).

$$
f_{x}(X)=\frac{\exp \left(-\frac{1}{2}\left(\frac{x-\mu}{\sigma}\right)\right)}{\sigma \sqrt{2 \pi}}
$$

for $-\infty \leq \mathrm{x} \leq \infty$.

This range of $-\infty \leq \mathrm{x} \leq \infty$ can cause problems when a normal distribution is used as a basis for a Monte Carlo analysis in which the entire range of values is randomly sampled [24]. This can give rise to a few very small numbers (sometimes negative) and very large numbers which, in certain analyses, can cause numerical instability. In order to overcome this problem the normal distribution is sometimes truncated so that only values falling within a specified range are considered valid [21].

\subsection{Coefficient of variation and characteristic value}

While the standard deviation is a useful indicator of the amount of scatter in a variable, the degree of dispersion is easier to see in context if it is expressed in terms of the coefficient of variation $(\mathrm{COV})$, which is the ratio of the standard deviation $(\delta)$ divided by the average $\left(X_{\text {mean }}\right)$.

$$
C O V=\frac{\delta}{X_{\text {mean }}}
$$

The COV is a dimensionless measure of the amount of scatter [25]. In Hungarian and especially international literature many recommendations can be found for COV values. During a former research, based on the literature data and on own series of laboratory experiments, intervals (Fig. 2 and Table 5) were determined for $\mathrm{COV}$ values of shear strength parameters: shear strength $(\tau)$, angle of internal friction $(\varphi)$ and cohesion (c) $[26]$.

Table 5 Recommended intarvals for $C O V$ values

\begin{tabular}{llll}
\hline Category & $\operatorname{COV}(\tau)$ & $\operatorname{COV}(\varphi)$ & $\operatorname{COV}(\mathrm{c})$ \\
\hline very low & $0.00-0.04$ & $0.00-0.08$ & $0.00-0.25$ \\
low & $0.041-0.10$ & $0.081-0.13$ & $0.251-0.40$ \\
medium & $0.101-0.20$ & $0.131-0.25$ & $0.401-0.55$ \\
high & $0.201-0.30$ & $0.251-0.40$ & $0.551-0.70$ \\
very high & $0.301-$ & $0.401-$ & $0.701-$ \\
\hline
\end{tabular}

The coefficient of variation is useful because the standard deviation of data must always be understood in the context of the mean of the data. In contrast, the actual value of the $C O V$ is independent of the unit in which the measurement has been taken, so it is a dimensionless number. For comparison between data sets with different units or widely different means, one should use the coefficient of variation instead of the standard deviation.

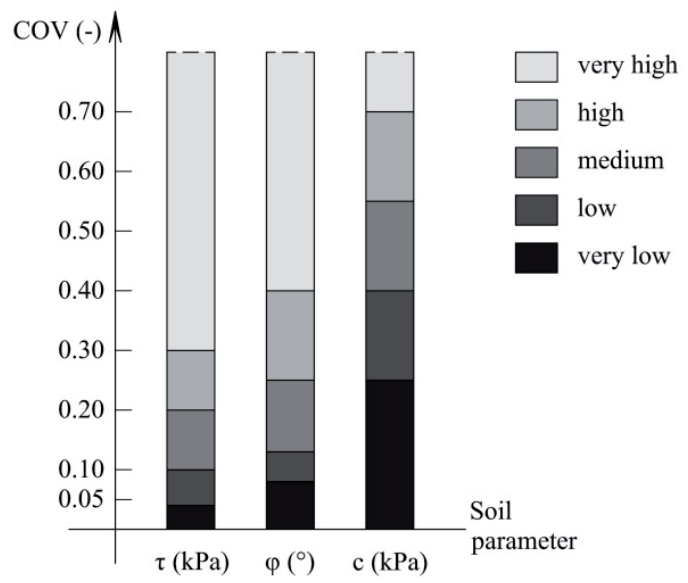

Fig. 4 Demonstration of recommended intervals for COV values 
In Eurocode 7 the material properties, effects and resistance are introduced into design as characteristic values with a prescribed probability of not being exceeded in a hypothetically unlimited test series. [27]. The characteristic value can be determined with the help of coefficient of variation. The wellknown formula for calculating the characteristic value is shown in Eq. (6).

$$
X_{x}=X_{m} \cdot\left(1 \pm k_{n} \cdot C O V\right)
$$

where $X_{k}$ is the characteristic value, $X_{m}$ is the mean value (normal distribution is assumed), $k_{n}$ is a statistical coefficient that depends on the number of the samples $(n)$ and the value which is relevant for the examination. To determine a lower characteristic value, $k_{n}$ is calculated as in Eq. (7).

$$
k_{n}=1.64 \cdot \sqrt{\frac{1}{n}}
$$

\section{Monte Carlo simulation}

The exact origin of the method is unexplained due to mismatching descriptions. According to the most probable one, the method's early versions were developed at the end of the 19th century, but became commonly used only after the appearance of the first computers. The first known calculation which was carried out with it was in connection with the Manhattan Project and the idea of using the Monte Carlo simulation came from Stanislaw Ulam and John Neumann. The neutron diffusion in fissionable material was modelled with random variables in their work [28].

Monte Carlo is a stochastic simulation method which performs a set of analysis by creating models of possible data from a range of values according to the probability distribution of the parameter. It can be applied for any factor that has inherent uncertainty. During the simulation the result is calculated each time using a different set of random values from the probability functions. Monte Carlo simulation produces distributions of possible outcome values.

The number of the realizations usually varies between $10^{4}$ and $10^{8}$ in civil engineering calculations depending on the number and distribution of the random variables [29].

There are a couple of parameters which can be defined as a random variable in case of the stability analysis of a flood protection dike. These include, but are not limited to:

- geometrical dimensions, as dike height, crest width, slope inclination;

- soil parameters, as the values of shear strength parameters, layer thicknesses;

- water level.

\section{Regulation and standards for safety of flood control levees}

In Hungary most of the flood control structures were built and installed between 1840 and 1930 [30]. Basically these dikes mean the country's main flood control system. The maintenance of flood protection works has always been in accordance with the currently valid regulation or standard. The development of the standards for flood control levees is described briefly in the followings. In 1985 MSZ-10-429:1984 Standard was introduced which was valid from 01 July 1985 until 01 January 1999. This standard defines safety factors for different failure mechanisms of a dike. Since 1999 MSZ 15292:1997 Standard has been in force instead of the above mentioned norm. The prescribed values of factor of safety are summarized in Table 3. These values are valid for a dike section which has not been crossed by an ancient riverbank [31].

In Eurocode 7 the design of slopes and embankments is covered by Sections 11 ('Overall stability') and 12 ('Embankments') of Part 1 [27]. GEO limit state refers to slope stability and three Design Approaches are offered (DA1, DA2 and DA3) in which different partial factors are defined for the calculations.

Table 6 Factor of safety values in MSZ 15292:1997 Standard

\begin{tabular}{lll}
\hline Failure mechanism & $\begin{array}{l}\text { FS } \\
\text { for design flood level }\end{array}$ & $\begin{array}{l}\text { FS } \\
\text { for crest level }\end{array}$ \\
\hline Hydraulic failure & 1.70 & 1.30 \\
Upstr./downstr. slope stability & 1.50 & 1.30 \\
Stability of floodwalls & 2.00 & 1.50 \\
Seepage under floodwalls & 1.80 & 1.50 \\
Stability of seepage canals & 1.50 & 1.30 \\
\hline
\end{tabular}

In practise, in case of a flood dike with no surface load on it, the partial factors are the followings:

$$
\begin{array}{ll}
- & \gamma_{\mathrm{G}}=1.00 \\
- & \gamma_{\varphi}=1.25, \\
- & \gamma_{\mathrm{c}}=1.25, \\
- & \gamma_{\mathrm{Re}}=1.00
\end{array}
$$

Hence the safety due to characteristic value is 1.25 .

In the Hungarian National Annex, compared to original 1.25 recommendation shear strength parameters, $\gamma_{\varphi}=\gamma_{c}=1.35$ was defined [32]. Table 7 summarizes the safety factors for slope stability.

Table 7 Factor of safety values of different standards

\begin{tabular}{lll}
\hline Standard & $\begin{array}{l}\text { FS } \\
\text { for design flood level }\end{array}$ & $\begin{array}{l}\text { FS } \\
\text { for crest level }\end{array}$ \\
\hline MSZ 15292:1997 & 1.50 & 1.30 \\
Eurocode 7 (EU) & 1.25 & 1.25 \\
Eurocode 7 (HUN) & 1.35 & 1.35 \\
\hline
\end{tabular}


The input parameters of Hungarian Standard and Eurocode 7 differ. MSZ 15292:1997 uses the mean values of soil parameters, while in Eurocode 7 the characteristic values have to be calculated. Therefore it is clear that the overall safety (reliability) of the different methods cannot be compared based on the safety factors only. In Chapter 6 the methods are compared based on computing the probability of failure.

\section{Geometry and soil parameters}

A common layout of flood protection dike is considered for the study. The cross section is shown in Fig. 5 representing a $5.0 \mathrm{~m}$ high embankment of crest width $5.0 \mathrm{~m}$ and having side slopes of $1 \mathrm{~V}: 3 \mathrm{H}$.

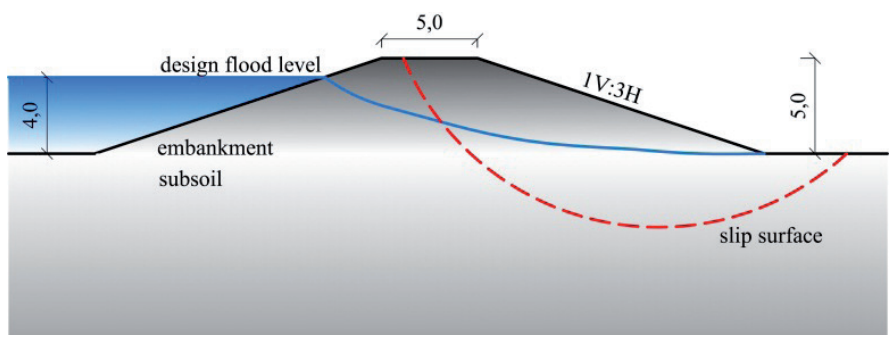

Fig. 5 Cross section of the examined embankment

A homogeneous dike section was assumed for the study. The shear strength parameters have the main effect on the stability of a slope, therefore angle of friction and cohesion are considered as random variables. The statistical coefficients of soil parameters used in the calculation are summarized in Table 8.

Table 8 Statistical coefficients of soil parameters of the dike

\begin{tabular}{llll}
\hline Soil parameter & COV & $\mathrm{n}$ & $\mathrm{k}_{\mathrm{n}}$ \\
\hline Unit weight $\left[\mathrm{kN} / \mathrm{m}^{3}\right]$ & 0 & - & - \\
Angle of friction $\left[^{\circ}\right]$ & 0.10 & 5 & 0.733 \\
Cohesion $[\mathrm{kPa}]$ & 0.20 & 5 & 0.733 \\
\hline
\end{tabular}

Characteristic values are inferior approximations of mean values at a confidence level of 95\%. 5 samples $(n)$ were taken into consideration as it is a common exploration method of a dike section to create 5 boreholes (one on the crest and twotwo on upstream and downstream slopes and toes). Equation (8) and (9) show examples how to calculate characteristic and mean values from each other. Considering $\mathrm{c}_{\text {mean }}=15.0 \mathrm{kPa}$ and the parameters in Table 8, the characteristic value is calculated as follows:

$$
c_{k}=15.00 \mathrm{kPa} \cdot(1-0.733 \cdot 0.20)=12.80 \mathrm{kPa}
$$

Similarly, the mean value can be re-calculated from characteristic value. Assuming $15 \mathrm{kPa}$ as the characteristic cohesion value of a soil, the mean value is determined as:

$$
c_{\text {mean }}=15.00 \mathrm{kPa} /(1-0.733 \cdot 0.20)=17.58 \mathrm{kPa}
$$

\section{Examination method, results}

The calculations were carried out with GeoStudio 7.10 GeoSlope software. The analysis is based on Bishop's slope stability method (Fig. 6). The factor of safety values were validated in Plaxis 2D (Fig. 7). Design flood level is $1.0 \mathrm{~m}$ below the crest level. The assumed unit weight is $19.50 \mathrm{kN} / \mathrm{m}^{3}$.

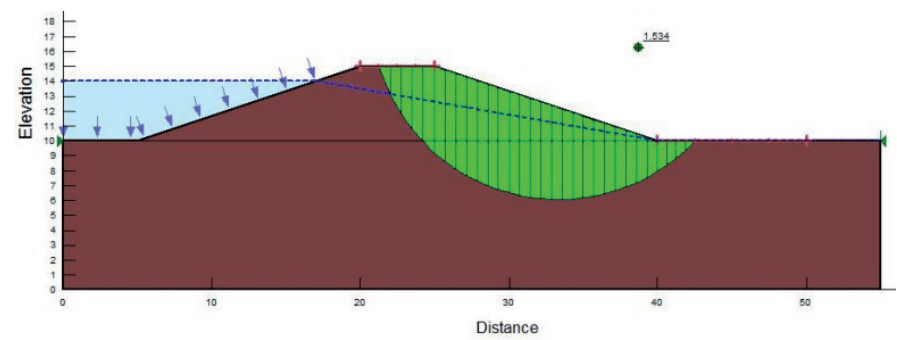

Fig. 6 Model in GeoSlope software, $\mathrm{FS}=1.53$

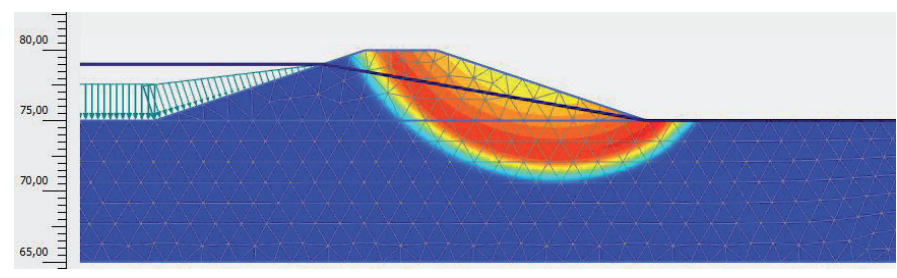

Fig. 7 Validation model in Plaxis 2D software, $F S=1.50$

The Monte Carlo method with factor of safety distribution calculation is implemented in the software. The analysis involved $10^{4}$ realisations which is sufficient to generate smooth distributions of the outputs. The distribution of factor of safety is considered as normal distribution similarly to the input data (Fig. 8).

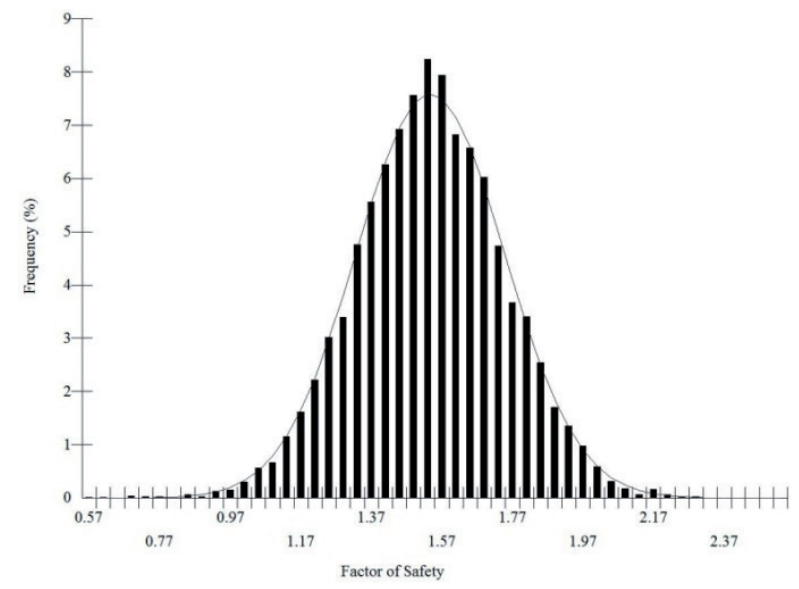

Fig. 8 Probability density function of calculated factor of safety values

The examination strategy is summarised in the followings:

- Step 1: set the characteristic values of soil parameters to exactly reach the $1.35 \mathrm{FS}$ value and run probabilistic anylsis.

- Step 2: fulfil the analysis with calculated mean values.

- Step 3: calculate $\beta$ to EC 7 (EU) case with Eq. (10).

$$
\beta=(1.25-1.00) / \delta
$$


Hence the probability of failure values can be evaluated and compared for the three different approaches. Input data and calculated values are summarised in Table 9 and Table 10.

Table 9 Input data and calculated values for design flood level

\begin{tabular}{llllll}
\hline \multicolumn{2}{c}{ MSZ 15292 } & \multicolumn{3}{r}{ EC 7 (HUN) } & \multicolumn{2}{c}{ EC 7 (EU) } \\
\hline$\varphi_{\text {mean }}\left({ }^{\circ}\right)$ & 9.04 & $\varphi_{\mathrm{k}}\left(^{\circ}\right)$ & 8.38 & $\varphi_{\mathrm{k}}\left(^{\circ}\right)$ & 8.38 \\
$\mathrm{c}_{\text {mean }}(\mathrm{kPa})$ & 14.53 & $\mathrm{c}_{\mathrm{k}}(\mathrm{kPa})$ & 12.40 & $\mathrm{c}_{\mathrm{k}}(\mathrm{kPa})$ & 12.40 \\
$\mathrm{FS}(-)$ & 1.54 & $\mathrm{FS}(-)$ & 1.35 & $\mathrm{FS}(-)$ & 1.25 \\
$\beta(-)$ & 2.558 & $\beta(-)$ & 1.945 & $\beta(-)$ & 1.389 \\
$\mathrm{P}_{\mathrm{f}}(-)$ & 0.0056 & $\mathrm{P}_{\mathrm{f}}(-)$ & 0.0252 & $\mathrm{P}_{\mathrm{f}}(-)$ & 0.0825 \\
$\delta(-)$ & 0.210 & $\delta(-)$ & 0.180 & $\delta(-)$ & 0.180 \\
\hline
\end{tabular}

Table 10 Input data and calculated values for crest water level

\begin{tabular}{llllll}
\hline \multicolumn{2}{c}{ MSZ 15292 } & \multicolumn{2}{r}{ EC 7 (HUN) } & \multicolumn{2}{c}{ EC 7 (EU) } \\
\hline$\varphi_{\text {mean }}\left({ }^{\circ}\right)$ & 9.50 & $\varphi_{\mathrm{k}}\left({ }^{\circ}\right)$ & 8.80 & $\varphi_{\mathrm{k}}\left({ }^{\circ}\right)$ & 8.80 \\
$\mathrm{c}_{\text {mean }}(\mathrm{kPa})$ & 15.18 & $\mathrm{c}_{\mathrm{k}}(\mathrm{kPa})$ & 12.95 & $\mathrm{c}_{\mathrm{k}}(\mathrm{kPa})$ & 12.95 \\
$\mathrm{FS}(-)$ & 1.54 & $\mathrm{FS}(-)$ & 1.35 & $\mathrm{FS}(-)$ & 1.25 \\
$\beta(-)$ & 2.488 & $\beta(-)$ & 1.883 & $\beta(-)$ & 1.344 \\
$\mathrm{P}_{\mathrm{f}}(-)$ & 0.0068 & $\mathrm{P}_{\mathrm{f}}(-)$ & 0.0303 & $\mathrm{P}_{\mathrm{f}}(-)$ & 0.0895 \\
$\delta(-)$ & 0.217 & $\delta(-)$ & 0.186 & $\delta(-)$ & 0.186 \\
\hline
\end{tabular}

\section{Conclusions}

Conventional slope practice based on the factor of safety cannot explicitly address uncertainty [33]. Practicing engineers and researchers have been concerned with the interpretation of safety for a long time. How safe is a structure? Is it safe enough? Answering these questions was a result of a long historical process. Reliability-based calculation is the best available method. Previously, different safety factors were specified with various input parameters. The comparison of these cannot be performed with the traditional techniques, only based on reliability methods as described above in the article.

Reliability-based design methods have not been commonly used in geotechnics, however, the uncertainty is particularly emphasized due to the relatively wide range of soil parameters compared to other construction materials (e.g. concrete, steel). Monte Carlo analysis is a statistical tool which is capable of calculating the probability of failure based on the input parameters. These parameters are characterised by their distribution.

As a conclusion, it can be stated that the calculation based on the traditional MSZ 15292:1997 Standard gave the highest level of safety $\left(\mathrm{P}_{\mathrm{f}}=0.0056\right.$ for design flood level). The Eurocode 7 calculation resulted in a higher probability of failure $\left(\mathrm{P}_{\mathrm{f}}=0.0252\right.$ for design flood level), which value is approximately five-times higher. The trend is similar with the assumption of crest level water (Table 10).

The difference in target safety factors between the 1.35 value of Hungarian recommendation and 1.25 value in the original version of Eurocode 7 also has a big influence (three-time difference) on probability of failure.
Calculation methods, using probability of failure, have not been developed for designers yet, but as the example of this article shows, it is fundamental for the interpretation of safety.

\section{References}

[1] Nagy, L. "Hydraulic failure probability of a dike cross section." Periodica Polytechnica Civil Engineering. 55(2), pp. 83-89.

DOI: 10.3311/pp.ci.2008-2.04

[2] Takács, A. "Karakterisztikus értékek meghatározásának új módszere nem független talajjellemzők esetén." (New method for the calculation of the characteristic values of correlated soil parameters.) Proceedings of ÉPKO-2012, pp. 372-380., Csíksomlyó, Romania. 2012. (in Hungarian).

[3] Duncan, J. M. "Factors of safety and reliability in geotechnical engineering." Journal of Geotechnical and Geoenvironmental Engineering. 126(4), pp. 307-316. 2000. DOI: 10.1061/(ASCE)1090-0241

[4] Zhang, J., Huang H. W. "Risk assessment of slope failure considering multiple slip surfaces." Computers and Geotechnics 74, pp. 188-195. 2016. DOI: 10.1016/j.compgeo.2016.01.011

[5] Middlebrooks, T. A. "Earth-dam Practice in the United States." Transactions of the American Society of Civil Engineers. 1953.

[6] ICOLD (International Commission on Large Dams). "Lessons from Dam Incidents." ICOLD Bulletin. 1974, 1981.

[7] ICOLD (International Commission on Large Dams). "Deterioration of dams and reservoirs." ICOLD Bulletin. 1984.

[8] ICOLD (International Commission on Large Dams). "Word Register of Dams." ICOLD bulletin. 1984.

[9] ICOLD (International Commission on Large Dams). "Dam failures Statistical Analysis." ICOLD Bulletin 99. 1995.

[10] Gruner, E. "The mechanism of dam failure." Proc. $9^{\text {th }}$ Congress, Int. Commission on Large Dams, Istanbul, 1967, Question 34, Rep. 12, 197-205. 1967.

[11] Takase, K. "Statistic study on failure, damage and deterioration of earth dams in Japan." 9th ICOLD Congress, pp. 1-19. 1967.

[12] Babb, A. O., Mermel, T. W. "Catalog of Dam Disaster, Failures and Accidents." Bureau of Reclamation, Washington, DC. 1968.

[13] Foster M., Fell R., Spannagle M. "The statistics of embankment dam failures and accidents." Canadian Geotechnical Journal. 37(5), pp. 10001024. 2000. DOI: 10.1139/t00-030

[14] Krol, P. "Analiza waniejszyn awarii walóv preciwpowodziowych." (Analysis of failure mechanisms of levees). Polsce Gosp. Wodna. 43, pp. 135-139. 1983. (in Polish)

[15] Sametz, L. "Beitrag zur Frage der Flutwellenbildung bei progressiven Dammbrüchen infolge von Überströmung." (Contribution to the question of the role of flood waves in progressive dam failures due to overflow). Dissertation on Technical University of Graz. 1981. (in German)

[16] Fukunari, K. "The Tone River Case and others. Safety of River Levee." In: Japan Conference, Power Point presentation, Tokyo, Japan, Nov. 2008

[17] Baars, S., Van Kempen, I. M. "The Causes and Mechanisms of Historical Dike Failures in the Netherlands." E-WAter, Official Publication of the European Water Association (EWA), 2009.

[18] Horlacher, H.-B. "Analyse der Deichbrüche an Elbe und Mulde während des Hochwassers im Bereich Sachsen." TU Dresden, Institut für Wasserbau und Technische Hydromechanik, im Auftrag der Landestalsperrenverwaltung des Freistaates Sachsen. 2005. (in German)

[19] Möllmann, A. F. D., Vermeer, P. A. "Reliability analysis of a dike failure." 18th EYGEC, Ancona, Italy, 2007.

[20] Nagy, L. "Gátszakadások a Kárpát-medencében, 1. kötet Gátszakadások kialakulásának körülményei." (Dike breaches in the Carpathian Basin, $1^{\text {st }}$ chapter Circumstances of the emergence of dike breaches). Országos Vízügyi Főigazgatóság. 2016. (in Hungarian) 
[21] Phoon, K. K., Ching, J. Y. (eds.) "Risk and Reliability in Geotechnical Engineering." CRC Press, 2015.

[22] Danka, J. "Probability of failure calculation of dikes based on Monte Carlo simulation." In: Proceedings of 21st European Young Geotechnical Engineers Conference (EYGEC), Rotterdam. 2011.

[23] Danka, J., Zhang, L. M. "Dike failure mechanisms from the perspective of risk assessment." In: Geotechnical Safety and Risk IV. Li, D. Q. (ed.) pp. 251-256, CRC Press. 2013. DOI: 10.1201/b16058-36

[24] Gong, W., Juang, C., Martin, J., II, Ching, J. "New Sampling Method and Procedures for Estimating Failure Probability." Journal of Engineering Mechchanics. 142(4), 04015107, 2015.

DOI: 10.1061/(ASCE)EM.1943-7889.0001041

[25] Rétháti, L. "Valószinüségelméleti megoldások a geotechnikában." (Probabilistic solutions in geotechnics), Akadémiai Kiadó, Budapest, 1988. (in Hungarian)

[26] Kádár, I. "Talajmechanikai paraméterek megbízhatóságának elemzése." (Reliability analysis of soil parameters), In: Proceedings of MérnökgeológiaKőzetmechanika konferencia 2013, Budapest, (Török, Á., Görög, P., Vásárhelyi, B.(eds.)) 2013. (in Hungarian)
[27] Bond, A., Harris, A. “Decoding Eurocode 7.” Taylor \& Francis, London and New York, pp. 151-153. 2008.

[28] Hammersley, J. "Monte carlo methods." Springer Science \& Business Media, 2013

[29] Faber, M. H. "Risk and safety in civil engineering." Lecture notes. Swiss Federal Institute of Technology, ETH Zurich, Switzerland. 2007.

[30] Nagy, L., Szepessy, J., Tóth, S., Vágó, J., Zorkóczy, Z. "Arvizvédelmi gátak épitése és fenntartása." (Construction and maintenance of flood protection dikes). Országos Vízügyi Hivatal, Budapest. 1987. (in Hungarian)

[31] MSZ 15292:1997 (Standard)

[32] MSZ EN 1997-2:2008 (Standard)

[33] El-Ramly H., Morgenstern N. R., Cruden D. M. "Probabilistic slope stability analysis for practice." Canadian Geotechnical Journal. 39(3), pp. 665-683. 2002. DOI: 10.1139/t02-034 